\title{
SCINTIGRAPHY OF THE HEPATOBILIAR SYSTEM IN PATIENTS WITH PULMONARY TUBERCULOSIS
}

\author{
CAMARGO R. S. A. (1), SILVA E. T. (2), GRIVA B. L. (3), PEREIRA P. C. M. (4)
}

(1) Nuclear Medicine Unit, Botucatu School of Medicine, São Paulo State University, UNESP, Botucatu, São Paulo, Brazil; (2) UNIP, São Paulo, Brazil; (3) Department of Tropical Diseases and Diagnostic Imaging, Botucatu School of Medicine, São Paulo State University, UNESP, Botucatu, São Paulo, Brazil; (4) Department of Tropical Diseases and Diagnostic Imaging, Botucatu School of Medicine, São Paulo State University, UNESP, Botucatu, São Paulo, Brazil.

ABSTRACT: The objective of this paper was to evaluate the hepatobiliary function of patients with pulmonary tuberculosis under triple treatment, using the technetium$99 \mathrm{~m}$-DISIDA ( ${ }^{99 \mathrm{~m}} \mathrm{Tc}$-DISIDA) hepatobiliary scintigraphy. Ten men and three women with pulmonary tuberculosis were subjected to hepatobiliary scintigraphy at the beginning of triple treatment (M1) and two months after it (M2). Patients were from the urban area, of low socioeconomic level, malnourished, and chronic alcohol and/or tobacco users. Ten normal individuals were evaluated as controls. Radiotracer images were acquired on a computerized gamma camera (Orbiter-Siemens) and $T_{1 / 2}$ uptake and excretion values were calculated. Nutritional status and serum hepatic enzyme levels for each patient were evaluated at M1 and M2. None presented clinical or laboratory antecedent of hepatobiliary disease. At M1, there were no hepatic serum or kinetic alterations of the ${ }^{99 \mathrm{~m}} \mathrm{Tc}$-DISIDA. At M2, patients presented better nutritional conditions than at $\mathrm{M} 1$; there was increased serum aspartate aminotransferase (AST) and reduced excretion time for ${ }^{99 \mathrm{~m}} \mathrm{Tc}$-DISIDA, which was interpreted as a more adaptive than toxic phenomenon, yet not all alterations were significant and none manifested clinically. Apparently, triple treatment acted on the liver inducing the P450 cytochrome enzymatic system, accelerating radiotracer excretion, which follows the same path as the bilirubins.

KEY WORDS: pulmonar tuberculosis, scintigraphy, hepatobiliar system, antituberculosis drugs.

\section{CORRESPONDENCE TO:}

RACHEL STARLING ASSAD DE CAMARGO, Setor Técnico de Medicina Nuclear, Hospital das Clínicas, UNESP, 18618-000, Botucatu, SP, Brasil. Phone: 0 XX 14 3811 6133. Fax: 0 XX 143815 5614. Email: racamargo@fmb.unesp.br 


\section{INTRODUCTION}

Tuberculosis is still a serious public health problem in Brazil. Since the 1970s, the short term triple scheme (six months) with isoniazid (INH), rifampicin (RFP) and pyrazinamide (PRZ) has had considerable success. However, these antituberculosis drugs are potentially hepatotoxic, particularly when associated (1).

Biotransformation of $\mathrm{INH}$ mainly occurs in the liver by acetylation by $\mathrm{N}$ acetyltransferase, producing toxic metabolites such as monoacetylhydrazine $(20,21$, 22). $\mathrm{N}$-acetyltransferase presents genetic polymorphism with bimodal distribution in the population, documented by the presence of both rapid and slow acetylator individuals (18). The relative frequencies of these phenotypes differ between geographic areas and ethnic groups. To prevent potential adverse manifestations, exposure to antituberculosis drugs should be preceded by determining INH acetylator phenotype. There are indications that rapid acetylators are more susceptible to hepatotoxicity by $\mathrm{INH}$, since they present a greater quantity of $\mathrm{N}$-acetyltransferase and therefore acetylize INH in monoacetylhydrazine more rapidly (18). However, this hypothesis still remains unclarified (12).

Besides genetically determined enzymatic polymorphism, biotransformation of drugs by the liver is influenced by age, alcoholism, tobacco use, nutrition, and advancedstage tubercular and hepatic diseases; these are considered risk factors that create predisposition to hepatotoxicity from antituberculosis drugs $(9,12,15,19,27)$.

Iminoacetic acid (IDA) and its analogs labeled with ${ }^{99 \mathrm{~m}} \mathrm{Tc}$ are important radiotracers for exploring hepatocyte function and the perviousness of the biliary tree due to their high hepatic clearance and low dosimetry (14). Although scintigraphy is an important method for functional and structural examination of the liver (23), permitting evaluation of hepatic diseases, no studies exist in literature using scintigraphy to evaluate hepatocellular function in patients subjected to triple antituberculosis therapy. This work aims to evaluate hepatic alterations, which can occur during a treatment that has potentially toxic action on the liver, using the hepatobiliary scintigraphy.

\section{PATIENTS AND METHODS}

This study was approved by the Research Ethics Committee of the Botucatu Medical School, São Paulo State University. Thirteen pulmonary tuberculosis patients were studied. They were hospitalized at the University Hospital between July 2001 and 
September 2002. There were 10 males (77\%) and 3 females (23\%) with mean age of $43 \pm 12$ years, ranging from 21 to 59 years, of low socioeconomic level $(77 \%)$, alcohol drinkers $(61 \%)$ and/or tobacco users $(92 \%)$, and rapid $(45 \%)$ and slow acetylators (55\%). Ethnicity was: nine whites (69\%), two mixed-race (15\%), and two blacks (15\%). Each patient answered a specific questionnaire on clinical history and socioeconomic profile.

Exclusion criteria were: those who did not sign the informed consent form; those who were pregnant; minors under eighteen years old; those in treatment or with a previous history of treatment for tuberculosis; and those with serological reaction to human immunodeficiency virus (HIV), to surface antigen of $B$ virus (HBsAg), or to the hepatitis $\mathrm{C}$ virus (HCV).

Immediately after diagnostic confirmation of tuberculosis, and before initiation of triple treatment - considered the start of the study (M1), all patients were subjected to clinical-nutritional evaluation, examinations of urine, serum and hematological biochemistry, and hepatobiliary scintigraphy. These exams were repeated two months after the start of triple treatment, when PRZ was withdrawn - considered the second moment of the study (M2). HIV, HCV, HbsAg serologies and acetylator phenotype determinations - colorimetric test in vitro $(10,13)$ - were only made at M1.

Scintigraphic evaluation of the hepatobiliary system was preceded by a $2-8 \mathrm{~h}$ fast. The standard dose of the radiopharmaceutical ${ }^{99 m}$ Tc-DISIDA (IPEN, USP, São Paulo) was $180 \mathrm{MBq}(5 \mathrm{mCi})$ [for adults of approximately $70 \mathrm{~kg}$ ]. Images of the anterior abdomen were taken immediately after intravenous administration of the radiotracer, with patients on a supine position. A low-energy and general-purpose collimator coupled to a computerized gamma camera (Orbiter, Siemens, Germany) was used. The dynamic study was recorded on a 64X64 matrix, with 60 images every 60 seconds, performed during 60 minutes on each patient. Images were processed on an ICON computer, software version 7.5 (Siemens - Germany). Regions of interest (ROIs) were drawn over the right superior projection of the liver and on the heart and time-activities curves were generated. $T_{1 / 2}$ uptake ( $\left.T_{1 / 2 \mathrm{Upt}}\right)$ and $T_{1 / 2}$ excretion ( $\left.T_{1 / 2 \mathrm{exc}}\right)$ values for ${ }^{99 \mathrm{~m}} \mathrm{Tc}$-DISIDA were calculated using an exponential adjustment of the curves by the least squares method (3). Ten healthy volunteers (controls) underwent scintigraphic evaluation of the liver and biliary tree at one moment (Table 1). 
Mean $(\mathrm{X})$, standard deviation (SD), and coefficient of variation (CV) were calculated for each variable at M1 and M2. Comparison between moments M1 and M2 was performed by the $t$ test for two paired samples (dependent) with calculations for $t$ and $p$ (8). The relationship between variables at each time was estimated by the Pearson correlation coefficient between pairs of variables. Results were considered significant when $p<0.05$; cases in which $0.05<p<0.10$ were assumed to have a tendency toward significance (8).

\section{RESULTS}

Patients showed significant improvement between the two studied times; mean M2 values for body mass index (BMI), and red corpuscle, hemoglobin and hematocrit levels were higher than at M1 (Table 1). From mean hepatic serum enzyme values, only AST was significantly higher at M2 than at M1; the other hepatic enzymes were higher at M2, but not significantly (Table 2).

The mean $\mathrm{T}_{1 / 2}$ uptake of ${ }^{99 \mathrm{~m}} \mathrm{Tc}$-DISIDA in the control group (CG) was significantly higher than in pulmonary tuberculosis patients at M2 (Table 3). In pulmonary tuberculosis patients, there were no significant differences of mean $T_{1 / 2}$ uptake value between $\mathrm{M} 1$ and $\mathrm{M} 2(\mathrm{M} 1=\mathrm{M} 2)$. For $\mathrm{T}_{1 / 2}$ excretion, there was no significant difference between $C G$ and patients, but at $M 2$ the patients had a lower mean $T_{1 / 2}$ excretion value than at $\mathrm{M} 1$. 
R. S. A. Camargo et al. SCINTIGRAPHY OF THE HEPATOBILIAR SYSTEM IN PATIENTS WITH PULMONARY TUBERCULOSIS. J. Venom. Anim. Toxins incl. Trop. Dis., 2006, 12, 2, p.238

Table 1: Nutritional status and hematometric values $(\mathrm{X} \pm \mathrm{SD})$ of patients with pulmonary tuberculosis at both study moments (M1, before triple treatment; $M 2$, two months after treatment initiation).

\begin{tabular}{|c|c|c|c|c|c|c|c|c|c|c|c|c|}
\hline & & & & & $\begin{array}{r}V \\
(10\end{array}$ & & & & & & & \\
\hline & M1 & M2 & M1 & M2 & M1 & M2 & M1 & M2 & M1 & M2 & M1 & M2 \\
\hline $\mathbf{X}$ & 55.3 & 61.9 & 20.49 & 23.08 & 9.08 & 7.67 & 4.53 & 5.06 & 35.92 & 42.0 & 11.50 & 13.74 \\
\hline SD & 10.2 & 12.9 & 3.6 & 4.54 & 2.95 & 2.89 & 0.48 & 0.74 & 4.25 & 4.57 & 1.67 & 1.54 \\
\hline Statistics & & & & & & & & & & & & \\
\hline & & & & & & & & & & & & \\
\hline Comments & & & M1 & & & & & & & & & \\
\hline
\end{tabular}

BMI : Body mass index; WBC: White blood cell; RBC: Red blood cell; Ht: Hematocrit; HB: Hemoglobin. 
Table 2: Serum biochemical parameters $(X \pm S D)$ of patients with pulmonary tuberculosis at both study moments (M1, before triple treatment; M2, two months after treatment initiation).

\begin{tabular}{|c|c|c|c|c|c|c|c|c|}
\hline & \multicolumn{2}{|c|}{$\begin{array}{c}\text { AST } \\
(4-20 \mathrm{mUi} / \mathrm{ml})^{*}\end{array}$} & \multicolumn{2}{|c|}{$\begin{array}{c}\text { ALT } \\
(2-18 \mathrm{mUi} / \mathrm{ml})\end{array}$} & \multicolumn{2}{|c|}{$\begin{array}{c}\text { ALP } \\
(3-126 \mathrm{mUi} / \mathrm{ml})\end{array}$} & \multicolumn{2}{|c|}{$\begin{array}{c}\text { Gamma-GT } \\
(15-73 \mathrm{mUi} / \mathrm{ml})\end{array}$} \\
\hline & M1 & M2 & M1 & M2 & M1 & M2 & M1 & M2 \\
\hline $\mathbf{X}$ & 13.00 & 23.55 & 14.15 & 20.77 & 110.92 & 133.31 & 66.0 & 105.75 \\
\hline SD & 7.85 & 18.11 & 14.32 & 26.48 & 46.23 & 75.74 & 45.67 & 102.47 \\
\hline
\end{tabular}

\begin{tabular}{lcccc}
\hline Statistics & $\mathrm{t}=2.659$ & $\mathrm{t}=0.934$ & $\mathrm{t}=1.020$ & $\mathrm{t}=1.296$ \\
& $p<0.05$ & $p>0.30$ & $p>0.30$ & $p>0.20$ \\
Comments & $\mathrm{M} 1<\mathrm{M} 2$ & $\mathrm{M} 1=\mathrm{M} 2$ & $\mathrm{M} 1=\mathrm{M} 2$ & $\mathrm{M} 1=\mathrm{M} 2$
\end{tabular}

AST: Aspartate aminotransferase; ALT: Alanine aminotransferase; ALP: Alkaline phosphatase; Gamma-GT: Gamma glutamyl transpeptidase; *: Reference values from local laboratory.

Table 3: $T_{1 / 2}$ uptake and $T_{1 / 2}$ excretion $(X \pm S D)$ of DISIDA [ ${ }^{99 m m} T c$ ] of controls (CG) and patients with pulmonary tuberculosis at both study moments (M1, before triple treatment; M2, two months after treatment initiation).

\begin{tabular}{|c|c|c|}
\hline Groups and moments & $\begin{array}{c}T_{1 / 2} \text { Uptake } \\
\text { (minutes) }\end{array}$ & $\begin{array}{c}\mathrm{T}_{1 / 2} \text { Excretion } \\
\text { (minutes) }\end{array}$ \\
\hline$C G(n=10)$ & $2.43 \pm 0.87$ & $24.61 \pm 6.93$ \\
\hline M1 $(n=13)$ & $1.88 \pm 0.75$ & $27.66 \pm 7.64$ \\
\hline M2 $(n=13)$ & $1.46 \pm 0.62$ & $22.08 \pm 4.09$ \\
\hline \multirow[t]{2}{*}{ Statistics } & CG=M1: $p>0.05$ & CG=M1: $p>0.05$ \\
\hline & $C G>M 2: p<0.05$ & $C G=M 2: p>0.05$ \\
\hline Comments & M1=M2: $p>0.10$ & M1>M2: $p<0.05$ \\
\hline
\end{tabular}

CG: Control group, normal individuals; Student's $t$ test. 


\section{DISCUSSION}

Aspartate aminotransferase (AST), alanine aminotransferase (ALT), alkaline phosphatase (ALP), gamma glutamyl transpeptidase (y-GT) levels, bilirubins, and hepatobiliary scintigraphy were normal at M1. There were significant changes in laboratory-clinical patient profile at $\mathrm{M} 2$, indicating improved general state. From the perspective of hepatic integrity and hepatocytic function indicators, there was a significant increase in AST serum activity and a significant decrease in mean $T_{1 / 2}$ value of ${ }^{99 \mathrm{~m}} \mathrm{Tc}$-DISIDA excretion at M2; in other words, radiotracer excretion was faster.

Although not specific, AST serum levels are also used as indicators of hepatic disease activity. In light lesions, AST serum elevation is due to the cytoplasmic component, and in grave mitochondrial lesions AST also participates; for this reason, high AST levels indicate complete alteration of hepatocytes (24). Thus significantly augmented AST levels at M2 can indicate hepatocyte alterations, which did not exist at M1, possibly associated with cellular injury and probably dependent on triple treatment. It must be remembered that most of the patients had antecedents of alcoholism, this can enable hepatocyte alterations caused by anti-tuberculosis drugs. This is reinforced by increases (not significant) in other enzymes values that reflect normal hepatocyte, such as ALT and y-GT, when they are compared to M1 values and reference norms. In summary, analysis of serum enzymatic levels suggests that triple treatment had some effect on the liver, which was apparently more adaptive than toxic as not all alterations occurred in a significant manner and none manifested clinically.

The enzymatic system associated with P450 cytochrome is the main responsible one for drug biotransformation in the human organism, and is highly concentrated in the smooth endoplasmic reticulum, microsomal hepatocyte fraction. Lewis et al. (16) suggested that enzymatic alterations occurring during treatment with drugs that induce microsomal enzymes or act on bilirubin metabolism probably translate to an intermediate stage between adaptation and hepatic toxicity. A very potent inducer for this system is phenobarbital (11); rifampicin and isoniazid are also recognized inductors (5). Apparently, rifampicin acts at various levels of organic anion hepatic transport and, in an analogous manner, radiotracers can compete with excretion of bilirubins (6). Even with prolonged treatment, rifampicin is associated with asymptomatic enzyme increase, which can be ignored unless the patient presents 
some clinical manifestation indicative of hepatic lesion (6). Therefore patients from this study could have presented a stimulated hepatic enzymatic system at M2.

The question of whether the acetylator phenotype creates a predisposition for hepatitis development due to medicaments is controversial. In the Brazilian population, the distribution of hydrazide acetylation phenotypes occurs in equal parts, with about $50 \%$ rapid and $50 \%$ slow acetylators (2), which agrees with patients in this work, in which $45 \%$ were rapid acetylators and $55 \%$ slow. In this study, of the six slow-acetylator patients, two presented increases in almost all hepatic enzymes at M2, while from the five rapid-acetylator patients, only one had increases in all hepatic enzymes at M2. Although these results tend to agree with those of Gronhagem-Riska et al. (12) and Martinez-Roig et al. (18), in which individuals with slow acetylator phenotype are more predisposed to develop hepatotoxicity, the small sample size does not permit a conclusion on the relation between acetylator phenotype and hepatotoxicity dependent on triple treatment.

The iminodiacetic acid derivatives, e.g., DISIDA, used on hepatobiliary scintigraphy are, like bilirubins, organic anions with transit similar to those through the liver and biliary pathway $(17,26)$. Thus the transport mechanism of bilirubin and the transit of bile, composed of water, inorganic electrolytes, organic anions, biliary acids, lipids, and proteins through the biliary system, are important models for understanding findings from hepatobiliary scintigraphy. At $M 2$, mean $T_{1 / 2}$ uptake for hepatocytes was not significantly different from M1. Considering the results for hepatic enzymes already discussed and knowing that eventual alterations in $T_{1 / 2}$ uptake not observed in this study indicated hepatocyte lesions (4), we can reiterate that possibly the alterations found at $\mathrm{M} 2$ depended more on a hepatic adaptive process for drugs that stimulated and were metabolized in the liver than on the hepatocyte lesion they induced. The significantly smaller $T_{1 / 2}$ uptake value of patients with tuberculosis at M2, compared with that of the control group, reinforces the hypothesis that livers of treated individuals were stimulated by triple treatment.

With regard to radiotracer excretion at $\mathrm{M} 2$, it is important to emphasize that the average duration of this process remained within normal standards described in literature (26) and did not differ from the mean value in the control group. However, it was significantly smaller than the mean value at $M 1$, indicating an increased excretion velocity at $\mathrm{M} 2$ in these patients. When scintigraphic evaluations of the liver and biliary tree with ${ }^{99 \mathrm{~m}} \mathrm{Tc}$-DISIDA are made after exposure to phenobarbital, 
alterations occur in radiotracer distribution and excretion (25). Although no information exists about the effects of triple treatment on bile flow, it cannot be ignored that this effect exists and influences the transit of isotopically labeled organic anions like ${ }^{99 \mathrm{~m}} \mathrm{Tc}$-DISIDA, since the drugs used in that treatment stimulate the liver similarly to phenobarbital $(5,11)$. So it is possible that active metabolites formed from biotransformation of these drugs may have stimulated hepatocyte function and, consequently, accelerate radiotracer excretion.

Furthermore, it is interesting that average ${ }^{99 \mathrm{~m}} \mathrm{Tc}$-DISIDA uptake time at M1 would have positive correlation with bilirubin levels at M1. This is understandable since their transit routes are the same, and there is competition between them for these routes (7). At $M 1$, there was no significant correlation between $T_{1 / 2}$ uptake and $T_{1 / 2}$ excretion of ${ }^{99 \mathrm{~m}} \mathrm{Tc}$-DISIDA. At M2, however, a significant direct correlation was seen between uptake velocities and excretion, i.e., increased excretion velocity appears to have been accompanied by greater radiotracer uptake. As a whole, this positive correlation between uptake velocities and excretion also reinforces that at M2 the liver was stimulated by triple treatment drugs. Our results suggest that scintigraphic evaluation shows functional hepatic alterations after triple treatment for pulmonary tuberculosis.

\section{REFERENCES}

1 ASKGAARD DS., WILCKE T., DOSSING M. Hepatotoxicity caused by the combined action of isoniazid and rifampicin. Thorax, 1995, 50, 213-4.

2 BEIGUELMAN B., RAMALHO AS., ARENA JFP., GARLIP CR. A acetilação da isoniazida em brasileiros caucasóides e negróides com tuberculose pulmonar. Rev. Paul. Med., 1977, 89, 12-5.

3 BEVINGTON PR., ROBINSON DK. Data reduction and error analysis for the physical sciences. 3.ed. New York: McGraw-Hill, 2003. 328p.

4 BROWN PH., JUNI JE., LIEBERMAN DA., KRISHNAMURTHY GT. Hepatocyte versus biliary disease: a distinction by deconvolutional analysis of technetium99m IDA time-activity curves. J. Nucl. Med., 1988, 29, 623-30.

5 BRUCKNER JV., WARREN DA. Toxic effects of solvents and vapors. In: KLAASSEN CD. Ed. Casarett and Doull's toxicology the basic science of poisons. 6.ed. New York: McGraw-Hill, 2003: 869-916. 
6 COLICHON AY., TORREZAN FILHO MA., STRAUSS E. Métodos diagnósticos: provas de função hepática. In: GAYOTTO LCC., ALVES VAF. Doenças do fígado e vias biliares. Rio de Janeiro: Atheneu, 2001: 139-49.

7 COMACK J., TOWSON ECJ., LOWER MA. Radiation protection and dosimetry in clinical practice. In: MURRAY IPC., Ell PJ. Eds. Nuclear medicine in clinical diagnosis and treatment. Edinburgh: Churchill Livingstone, 1994: 1371-88.

8 CURI PR. Metodologia e análise da pesquisa em Ciências Biológicas. 2.ed. Botucatu: Tipomic, 1998. 263p.

9 DURNAS C., LOI CM., CUSACK BJ. Hepatic drug metabolism and aging. Clin. Pharmacokinet., [serial online], 1990, 19, 359-89 [cited 2003 Jun 14]. Available from:

10 EIDUS L., VARUGHESE P., HODGKIN MM., HSU AH., MCRAE KB. Simplification of isoniazid phenotyping procedure to promote its application in the chemotherapy of tuberculosis. Bull. World Health Organ., 1973, 49, 50716.

11 GALI E., FEIJOO L. Citocromo P450 y su importância clínica. Revisión actualizada. Rev. Neuro-Psiquiatr., 2002, 65, 187-201.

12 GRONHAGEN-RISKA C., HELLSTROM PE., FROSETH B. Predisposing factors in hepatitis induced by isoniazid-rifampin treatment of tuberculosis. Am. Rev. Respir. Dis., 1978, 118, 461-6.

13 HODGKIN MM., EIDUS L., HAMILTON EJ. Screening of isoniazid inativators by dilution test. Bull. World Health Organ., 1974, 51, 428-30.

14 KOWALSKY RJ., RANDOLPH JP. Liver, Gallblader, Spleen and Bone Marrow. In: KOWALSKY RJ., PERRY JR. Ed. Radiopharmaceuticals in nuclear medicine practice (current practice in nuclear medicine). Norwalk: Appleton \& Lange, 1987: 271-314.

15 LESORBRE R., RUFINO J., TEYSSIER L., ARCHARD F., BREFORT C. Les ictères au cours du traitment par la rifampicine. Rev. Tuberc. Pneumol., 1969, 33, 353.

16 LEWIS JH., ZIMMERMAN HJ. Drug-induced liver disease. Med. Clin. North Am., 1989, 73, 775-92.

17 MADSEN MT., PONTO JL. Medical physics. Madson: Medical Physics Publishing, 1992. 107p. 
18 MARTINEZ-ROIG A., CAMI J., CLORENS-TEROL J., DE LA TORRE R., PERICH F. Acetylation phenotype and hepatotoxicity in treatment of tuberculosis in children. Pediatrics, 1986, 77, 912-5.

19 MEIRELLES DE SOUZA AF., SILVA AO., BALDI J., SOUZA TN., RIZZO PM. Alterações funcionais hepáticas induzidas pelo uso concomitante de isoniazida, pirazinamida e rifampicina no tratamento da tuberculose pulmonar. Arq. Gastroenterol., 1996, 33, 194-200.

20 MENDES RP. Tuberculose. In: MEIRA DA. Org. Terapêutica das doenças infecciosas e parasitárias. 2.ed. Rio de Janeiro: Editora de Publicações Científicas, 1994: 226-35.

21 MITCHELL JR., NELSON SD., THORGEIRSSON SS., McMURTRY RJ., DYBING E. Metabolic activation: biochemical basis for many drug-induced liver injuries. Prog. Liver Dis., 1976, 5, 259-79.

22 MITCHELL JR., THORGEIRSSON UP., BLACK M., TIMBRELL JA., SNODGRASS WR., POTTER WZ., JOLLOW HR., KEISER HR. Increased incidence of isoniazid hepatitis in rapid acetylators. Possible relation to hydrazine metabolites. Clin. Pharmacol. Ther., 1975, 18, 70-9.

23 NOGUERA ECA., WAFA H., NOGUERA EC. Centellografia hepatobiliar cuantitativa con 99m Tc DISIDA en sujetos normales y em cirroticos alcoholicos. Medicina, 1995, 55, 385-90.

24 PANTEGHINI M., FALSETTI F., CHIARI E., MALCHIODI A. Determination of aspartate aminotransferase AST isoenzymes in hepatic diseases - preliminary findings. Clin. Chim. Acta, 1983, 128, 133-40.

25 RADIOFARMÁCIA EM INTERNET. [cited 2003 Jul 09]. Available from:

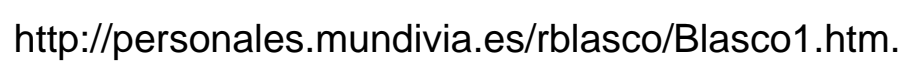

26 SODEE DB., VELCHIK MG., NOTO RJ., REILLEY J., ALAVI A. Gastrointestinal system. In: EARLY PJ., SODEE DB. Principles and practice of nuclear medicine. 2.ed. St. Louis: Mosby, 1995: 502-14.

27 WYNNE HA., COPE LH., MUTCH E., RAWLINS MD., WOODHOUSE KW., JAMES OF. The effect of age upon liver volume and apparent liver blood flow in healthy man. Hepatology, 1989, 2, 297-301. 